\title{
Quality of life in adolescents with hearing deficiencies and visual impairments
}

\author{
Vanthauze Marques Freire Torres', Christielle Lidianne Alencar Marinho², Carolina Gabriela Gomes de Oliveira ${ }^{3}$, \\ Sandra Conceição Maria Vieira ${ }^{4}$.
}

\author{
1) Physical Educator. Master of Hebiatry \\ 2) Nurse. Master of Hebiatria. \\ 3) Graduate in dentistry. Scientific initiation-PIBIC. \\ 4) Dentist. Doctor of Dentistry. \\ Institution: University of Pernambuco, UPE \\ Camaragibe / PE - Brazil. \\ Mailing address: Research Group for People with Disabilities, Graduate Program in Hebiatry - Faculty of Dentistry - University of Pernambuco (FOP/UPE) - Av. General \\ Newton Cavalcanti 1650 - Camaragibe / PE - Brazil - Zip Code: 54756-220 - E-mail: gppd@googlegroups.com
}

Article received on October 11, 2012. Article accepted on December 3, 2012.

\section{SUMMARY}

Introduction: The term quality of life (in Portuguese, Qualidade de Vida; QV) has been expanded and modified over the years and has come to signify social development in terms of education, health, and leisure as well as economic issues.

Objective: To analyze the perception of QV in adolescents with hearing and visual impairments and the effects of sociodemographic characteristics on the domains of QV.

Method: This descriptive series study comprised 42 adolescents aged 10 to 19 years who were students at Recife's state schools. The World Health Organization Quality of Life-Abbreviated questionnaire was used to evaluate QV. The data were analyzed using descriptive statistics and the Mann-Whitney and Kruskal-Wallis tests with a significance level of $\mathrm{p}<0.05$.

Results: The global perception of QV was higher among adolescents with visual impairments than among those with hearing impairments. Among the individual components of $\mathrm{QV}$, the environment domain garnered the lowest scores independent of the type of impairment. The subjects with visual impairments reported higher scores for social relationships, while the psychological domain scored higher among those with hearing impairments. The students integrated into normal classrooms perceived better QV in the psychological and social relationships domains than did those who sat in special classrooms.

Conclusion: The environmental domain was the worst component of the QV of handicapped adolescents, suggesting a need for greater investments in policies to improve the QV of this population.

Keywords: Quality of Life; Adolescent; Hearing Loss; Visually Impaired Persons.

\section{INTRODUCTION}

The term quality of life (in Portuguese, Qualidade de Vida; QV) appeared for the first time in a book about well being written in 1920 . However, it was not disseminated until the 1960s, when it was used in relation to policies that looked forward to a better standard of living, especially with regard to economic factors. Over the years, the concept grew to encompass parameters of social development, such as education, health, and leisure, as well as economic growth $(1,2)$.

The term QV appears frequently in health-related fields, where it is a perennial topic of discussion. The initial surge in the use of this concept was in its widest sense, as illustrated by its use by the World Health Organization, which defines quality of life as the individual's perception of his or her position in life with consideration of his or her culture and the values thereof and in relation to his or her objectives, expectations, standards of living, and major concerns $(3,4)$.
In recent decades, the growing interest in $\mathrm{QV}$ among the scientific community and the entire health sector has led to marked development of the multidimensional, individual, subjective, and multidisciplinary characteristics of this construct as well as the ways in which it links various health sectors. Although we refer to QV or quality of life as being widely accepted by the World Health Organization, we still do not see firm agreement in the literature as to the best definition for this construct $(5,6)$.

While searching for an assessment of the quality of life in its various dimensions, we noticed an increasing trend towards quantitative and multi-dimensional measurement in order to capture its exact nature. We believe that such information will help to evaluate the effectiveness, efficiency, and impact(s) of various treatments for handicapped people; define and validate treatment approaches; define strategies in the area of health; and monitor and maintain individuals' quality of life $(7,8)$. 
In spite of the growth in research output focused on the concept of quality of life, little study has been made of its features in the area of health for children and adolescents with disabilities in Brazil. There is, in fact, little concern for handicapped people in general. It is increasingly important to evaluate non-handicapped individuals alongside those who are impaired in some way, especially as technologies to aid those with impairments have become more important, although not necessarily significant, in the promotion of quality of life (9).

The 2010 Census performed by the Brazilian Institute of Geography and Statistics (IBGE) (10) indicates that there are 45.5 million people in Brazil with some kind of impairment, corresponding to $23.9 \%$ of the Brazilian population. However, according to documentation provided by the Ministry of Health in 1991, only $2 \%$ of these individuals had received any kind of assistance, whether private or from the public sector, and the advances in this area since that time have been insignificant overall. From the social and political viewpoints, the handicapped are still seen as a minority. This may be why the literature produced in this area is practically nonexistent (11).

Data from the Census of 2010 indicate that there are approximately 2.4 million people with a disability in Pernambuco, representing $27.5 \%$ of the State population. According to the census performed on schools in 2010 by the Pernambuco State Secretary of Education (SEDUC-PE) (12), there are 7212 students enrolled in the state school network who have some kind of disability. The number in Recife is 1931 students, representing a prevalence of $26.77 \%$ among the total State enrollment. Of the students with disabilities in Pernambuco, 25.54\% have hearing impairments and $4.40 \%$ have problems with sight. In the capital, Recife, the prevalence rates for these respective categories are $31.02 \%$ and $3.37 \%$ (12).

The assessment of quality of life in adolescents with disabilities is of the utmost importance because adolescence is a key phase for interventions and modification of life's habits. Regardless of the type of disability, this population deserves attention and dedicated policies, as their identities are in the process of being formed and an unsatisfactory quality of life at this time can have serious repercussions for their futures. This is the starting point for a discussion of and reflection on the quality of life of adolescents with disabilities with the ultimate goal of intervention, emancipation, and collaboration to yield a healthier adolescence. To this end, the objective of the present study was to analyze the perceptions of quality of life of adolescents with hearing and visual impairments and the effects of the sociodemographic characteristics of the studied population on the domains of QV.

\section{Methods}

This was a cross-sectional, descriptive study performed during November and December 2011 in 4 (four) schools of the state school network located in the city of Recife, Pernambuco.

In compliance with Resolution number 196/96 of the Health Ministry, which discusses Investigation Involving Human Beings in Brazil, the plan for this study was submitted to the University of Pernambuco's Ethics Committee under process number 150/11 and CAAE registration 0137.0.097.000-11. All participants were informed as to the objectives of the research, and each signed a Free and Clarified Consent Term (TCLE). For those participants who were minors, the TCLE was signed by the guardian.

The target population comprised adolescents according to the World Health Organization's definition, i.e., individuals aged between 10 and 19 years. They had impairments in vision or hearing and were enrolled in and regularly attending centers for learning.

As this was an exploratory study, the schools were deliberately chosen for their high numbers of students with such impairments. Subjects were included in the study on the basis of their desire to participate in the experiment. Therefore, all of the students were contacted and informed as to the nature and objectives of the study, and the group of 42 individuals consisted of those who volunteered to participate. Potential subjects who presented with associated cognitive deficits or were unable to understand the instrument used were excluded from the study.

The authors developed a questionnaire addressing the subjects' socio-demographic characteristics. Following the administration of this questionnaire, the instrument for the evaluation of Quality of Life by the World Health Organization (WHOQOL-BREF) was applied. This instrument was developed by the World Health Organization and tested and adapted to our language by Fleck et al (13) (2000). It consists of 26 questions distributed among 4 domains: physical, psychological, social relations, and environment. The domains are represented by various facets, and the corresponding questions were formulated to use a scale of responses of the Likert type, with scales for intensity (nothing to extremely), capacity (nothing to completely), frequency (never to always), and evaluation (very unsatisfied to very satisfied; really terrible to really good). According to Fleck et al. (14) (2000), the instrument is self-explanatory and can be self-administered, assisted by the interviewer, or, further still, administered by the interviewer. 
The instrument was applied in different ways in the subjects with visual handicaps and in those with hearing impairments. In the first group, it was administered in the form of an interview conducted by the researchers. In the second group, it was self-administered with the aid of an interpreter of sign language from the subject's own school in order to maintain a dialogue between the researchers and the participating students.

The data obtained using the WHOQOL-BREF were scored using the SPSS 20.0 statistical program, as recommended by the World Health Organization (The WhoqolGroup, 1998a) (15). Initially, the sample group was characterized using descriptive analysis, which included absolute and relative frequencies as well as measures of the centrality and variance represented by the mean and standard deviation. Then, the scores for the quality of life perceived in each domain were compared with respect to the socio-demographic characteristics of the subjects or other parameters using the Mann-Whitney and KruskalWallis non-parametric inferential statistical tests with a level of significance equal to 0.05 . These tests were used because the normality of the data could not be proven and the sample size was small.

\section{RESULTS}

Analysis of the socio-demographic questionnaire demonstrated that of the 42 adolescents, 37 (88.1\%) had hearing impairments and 5 (11.9\%) had vision impairments. Twenty-seven (64.3\%) were male and $15(35.7 \%)$ female. The majority $(35 ; 83.3 \%)$ were between 15 and 19 years of age, and most $(32 ; 76.2 \%)$ had reached the Fundamental II level of education (Table 1).

The deficiency was genetic in origin in 27 (64.3\%) of the subjects and acquired (i.e., through trauma or a specific illness) in 15 (35.7\%) (Table 1).

Most of the students (38;90.5\%) in question attended a regular classroom, i.e., were in classes that also included students who did not have a disability (Table 1).

Regardless of whether their disabilities were visual or auditory, the subjects recorded the lowest scores in the environmental domain or field of QV. The domain with the highest score differed between the groups, being the social relationships field for the visually disabled and the psychological field for the hearing impaired. When the entire population was analyzed as a whole, the lowest score was for the environment field and the highest for the psychological field. Comparison between students with different types of disabilities showed statistically significant differences in the psychological and social relations domain sub-scores as well as in the global QV (p $<0.05$ ) (Table 2).

Analysis of the effects of various socio-demographic characteristics on the global QV of the entire cross-section of adolescents showed that the group of students who were integrated into regular classrooms perceived a significantly higher $(\mathrm{p}=0.026)$ quality of life than did those in special classrooms (Table 3).

Higher scores for global QV were perceived by the 10-to-14-year-old age group, by males, by those studying at the fundamental Ilevel, and by those who lived with their parents than by their respective counterparts. However, none of these differences was significant $(\mathrm{p}>$ 0.05) (Table 3).

Examination of the effects of the socio-demographic characteristics on the physical field of the questionnaire showed a significant difference between the age groups, with 10-to-14-year old students recording higher scores in this field $(p=0.044)$. Female students, students at the fundamental I level, adolescents who lived with their parents, and students in regular classrooms had higher scores than their respective counterparts; however, none

Table I. Description of the socio-demographic characteristics of adolescents with hearing and visual impairments $(n=42)$ by absolute and relative frequencies.

\begin{tabular}{|c|c|c|c|c|c|c|}
\hline \multirow{3}{*}{ Variable } & \multicolumn{6}{|c|}{ Type of Impairment } \\
\hline & \multicolumn{2}{|c|}{$\begin{array}{c}\text { Visual } \\
(n=5)\end{array}$} & \multicolumn{2}{|c|}{$\begin{array}{l}\text { Hearing } \\
(n=37)\end{array}$} & \multicolumn{2}{|c|}{$\begin{array}{c}\text { Total } \\
(n=42)\end{array}$} \\
\hline & $n$ & $\%$ & $n$ & $\%$ & $n$ & $\%$ \\
\hline \multicolumn{7}{|l|}{ Age } \\
\hline 10 to 14 years & 0 & 0 & 7 & 18.9 & 7 & 16.7 \\
\hline 15 to 19 years & 5 & 100.0 & 30 & 81.1 & 35 & 83.3 \\
\hline \multicolumn{7}{|l|}{ Sex } \\
\hline Male & 3 & 60.0 & 24 & 64.9 & 27 & 64.3 \\
\hline Female & 2 & 40.0 & 13 & 35.1 & 15 & 35.7 \\
\hline \multicolumn{7}{|l|}{ Etiology } \\
\hline Acquired & 3 & 60.0 & 12 & 32.4 & 15 & 35.7 \\
\hline Genetic & 2 & 40.0 & 25 & 67.6 & 27 & 64.3 \\
\hline \multicolumn{7}{|l|}{ Level of Education } \\
\hline Fundamentall & 0 & 0 & 5 & 13.5 & 5 & 11.9 \\
\hline Fundamentalll & 3 & 60.0 & 29 & 78.4 & 32 & 76.2 \\
\hline High School & 2 & 40.0 & 3 & 8.1 & 5 & 11.9 \\
\hline \multicolumn{7}{|l|}{ Type of Classroom } \\
\hline Regular & 5 & 100.0 & 33 & 89.2 & 38 & 90.5 \\
\hline Special & 0 & 0 & 4 & 10.8 & 4 & 9.5 \\
\hline \multicolumn{7}{|l|}{ Living with Parents } \\
\hline Yes & 5 & 100.0 & 28 & 75.7 & 33 & 78.6 \\
\hline No & 0 & 0 & 9 & 24.3 & 9 & 21.4 \\
\hline
\end{tabular}


Table 2. Individual field and global quality of life scores of adolescents with hearing and visual impairments $(n=42)$ expressed as the mean and standard deviation (SD).

\begin{tabular}{|c|c|c|c|c|c|c|c|}
\hline \multirow[t]{2}{*}{ Quality of Life } & \multicolumn{2}{|c|}{$\begin{array}{l}\text { Type of Impairment } \\
\text { Visual }(n=5)\end{array}$} & \multicolumn{2}{|c|}{ Hearing $(n=37)$} & \multicolumn{2}{|c|}{$\begin{array}{l}\text { Total of Cross } \\
\text { Section }(n=42)\end{array}$} & \multirow[t]{2}{*}{ pValue } \\
\hline & Mean & SD & Mean & $S D$ & Mean & SD & \\
\hline $\begin{array}{l}\text { Physical } \\
\text { Psychological } \\
\text { Social Relations } \\
\text { Environment } \\
\text { Global Quality of Life (QV) }\end{array}$ & $\begin{array}{r}77.14 \\
83.33 \\
85.00 \\
60.00 \\
76.36 \\
\end{array}$ & $\begin{array}{l}9.64 \\
14.73 \\
20.74 \\
12.77 \\
13.24\end{array}$ & $\begin{array}{l}67.27 \\
67.34 \\
65.52 \\
55.99 \\
64.03\end{array}$ & $\begin{array}{l}16.15 \\
13.12 \\
21.62 \\
16.72 \\
12.80\end{array}$ & $\begin{array}{l}68.45 \\
69.24 \\
67.85 \\
56.47 \\
65.50\end{array}$ & $\begin{array}{l}15.77 \\
14.13 \\
22.20 \\
16.22 \\
13.31\end{array}$ & $\begin{array}{c}0.222 \\
0.014 * \\
0.044 * \\
0.565 \\
0.029 *\end{array}$ \\
\hline
\end{tabular}

(*): Significant difference at the level of $5.0 \%$.

of these differences was statistically significant $(p>0.05)$ (Table 4).

Examination of the psychological field verified that the students in regular classrooms scored significantly higher $(\mathrm{p}=0.022)$ in this field than did students in special classrooms (Table 4). The 10-to-14-year-old age group, males, those with acquired disabilities, those at the fundamental I level, and those who lived with their parents recorded higher scores in the psychological field than did their counterparts. However, none of these differences was significant $(\mathrm{p}>0.05)$ (Table 4).

Analysis of the field of social relations revealed that the 10-to-14-year-old age group, males, those who had genetic disabilities, high school students, students in regular classrooms, and adolescents who lived with their parents recorded higher scores than did their counterparts. However, none of these differences was significant $(p>0.05)$ (Table 4).

Analysis of the environment field showed that students in regular classrooms recorded significantly $(\mathrm{p}=$ $0.023)$ higher scores in this domain than did those in special classrooms (Table 4). The 10-to-14-year-old age group, males, those with genetic disabilities, students from ensino fundamental $I$, and adolescents who did not reside with their parents reported higher scores in this domain than did their counterparts. However, none of these differences was significant $(\mathrm{p}>0.05)$ (Table 4).

\section{DISCUSSION}

Quality of life has been discussed extensively in recent years. This may be due to the association of quality of life with the appearance and development of events that have come to compromise individuals' levels of health. In spite of the increase in interest in the quality of life, the literature contains few investigations focusing on
Table 3. Global quality of life scores expressed as the mean and standard deviation (SD) according to the socio-demographic characteristics of adolescents with disabilities $(n=42)$.

\begin{tabular}{|c|c|c|}
\hline \multirow[t]{2}{*}{ Variable } & \multicolumn{2}{|c|}{ Global Quality of Life } \\
\hline & Mean & SD \\
\hline \multicolumn{3}{|l|}{ Age } \\
\hline 10 to 14 years & 70.06 & 11.41 \\
\hline 15 to 19 years & 64.59 & 13.63 \\
\hline pValue & \multicolumn{2}{|c|}{$p^{(1)}=0.316$} \\
\hline \multicolumn{3}{|l|}{ Sex } \\
\hline Male & 65.67 & 13.83 \\
\hline Female & 65.20 & 12.80 \\
\hline pValue & \multicolumn{2}{|c|}{$p^{(1)}=0.655$} \\
\hline \multicolumn{3}{|l|}{ Etiology } \\
\hline Acquired & 65.50 & 14.99 \\
\hline Genetic & 65.50 & 12.59 \\
\hline pValue & \multicolumn{2}{|c|}{$p^{(1)}=0.751$} \\
\hline \multicolumn{3}{|l|}{ LevelofEducation } \\
\hline Fundamentall & 72.50 & 10.36 \\
\hline Fundamentalll & 64.16 & 12.36 \\
\hline High School & 67.11 & 21.16 \\
\hline pValue & \multicolumn{2}{|c|}{$p^{(2)}=0.344$} \\
\hline \multicolumn{3}{|l|}{ Classroom } \\
\hline Regular & 66.90 & 13.23 \\
\hline Special & 52.25 & 22.05 \\
\hline pValue & \multicolumn{2}{|c|}{$p^{(I)}=0.026 *$} \\
\hline \multicolumn{3}{|l|}{ Livingwith Parents } \\
\hline Yes & 66.51 & 13.62 \\
\hline No & 61.82 & 12.14 \\
\hline pValue & \multicolumn{2}{|c|}{$p^{(1)}=0.345$} \\
\hline
\end{tabular}

(*): Significant difference at $5.0 \%$.

(1): Mann-Whitney Test.

(2): KruskalWallis Test. 
Table 4. Quality of life scores by field expressed as the mean and standard deviation (SD) according to the socio-demographic characteristics of adolescents with disabilities $(n=42)$.

\begin{tabular}{|c|c|c|c|c|c|c|c|c|}
\hline \multirow{3}{*}{ Variable } & \multicolumn{8}{|c|}{ Field of Quality of Life } \\
\hline & \multicolumn{2}{|c|}{ Physical } & \multicolumn{2}{|c|}{ Psychological } & \multicolumn{2}{|c|}{ Social Relations } & \multicolumn{2}{|c|}{ Environment } \\
\hline & Mean & SD & Mean & SD & Mean & SD & Mean & SD \\
\hline \multicolumn{9}{|l|}{ Age } \\
\hline 10 to 14 years & 79.08 & 9.08 & 69.64 & 11.95 & 69.04 & 19.07 & 62.50 & 21.34 \\
\hline 15 to 19 years & 66.32 & 16.04 & 69.16 & 14.68 & 67.61 & 23.02 & 55.26 & 15.09 \\
\hline pValue & \multicolumn{2}{|c|}{$p^{(I)}=0.044^{*}$} & \multicolumn{2}{|c|}{$p^{(1)}=0.981$} & \multicolumn{2}{|c|}{$p^{(1)}=0.993$} & \multicolumn{2}{|c|}{$p^{(1)}=0.67 \mid$} \\
\hline \multicolumn{9}{|l|}{ Sex } \\
\hline Male & 66.79 & 17.57 & 69.59 & $13.3 \mid$ & 69.13 & 21.41 & 57.17 & 18.60 \\
\hline Female & 71.42 & 11.84 & 68.61 & 15.97 & 65.55 & 24.16 & 55.20 & 11.18 \\
\hline pValue & \multicolumn{2}{|c|}{$p^{(1)}=0.596$} & \multicolumn{2}{|c|}{$p^{(1)}=0.562$} & \multicolumn{2}{|c|}{$p^{(1)}=0.689$} & \multicolumn{2}{|c|}{$p^{(1)}=0.635$} \\
\hline \multicolumn{9}{|l|}{ Etiology of Impairment } \\
\hline Acquired & 68.33 & 14.90 & 70.27 & 14.92 & 67.77 & 23.54 & 55.62 & 16.50 \\
\hline Genetic & 68.51 & $|6.5|$ & 68.67 & 13.93 & 67.90 & 21.89 & 56.94 & 16.36 \\
\hline pValue & \multicolumn{2}{|c|}{$p^{(1)}=1.000$} & \multicolumn{2}{|c|}{$p^{(1)}=0.437$} & \multicolumn{2}{|c|}{$p^{(I)}=0.860$} & \multicolumn{2}{|c|}{$p^{(1)}=0.974$} \\
\hline \multicolumn{9}{|l|}{ Level of Education } \\
\hline Fundamentall & 75.00 & 12.62 & 75.00 & 6.58 & 70.00 & 19.18 & 70.00 & 20.79 \\
\hline Fundamentalll & 67.29 & 16.40 & 67.96 & 13.48 & 66.40 & 21.73 & 54.98 & 14.93 \\
\hline High School & 69.28 & 15.48 & 71.66 & 23.08 & 75.00 & 30.61 & 52.50 & 16.44 \\
\hline pValue & \multicolumn{2}{|c|}{$p^{(2)}=0.728$} & \multirow{2}{*}{\multicolumn{2}{|c|}{$p^{(2)}=0.416$}} & \multirow{2}{*}{\multicolumn{2}{|c|}{$p^{(2)}=0.512$}} & \multicolumn{2}{|c|}{$p^{(2)}=0.293$} \\
\hline \multicolumn{5}{|l|}{ Classroom } & & & & \\
\hline Regular & 69.17 & 16.17 & 70.72 & 13.98 & 69.73 & 22.46 & 57.97 & 16.25 \\
\hline Special & 61.60 & 10.25 & 55.20 & 5.24 & 50.00 & 6.80 & 42.18 & 5.98 \\
\hline pValue & \multirow{2}{*}{\multicolumn{2}{|c|}{$p^{(1)}=0.153$}} & \multirow{2}{*}{\multicolumn{2}{|c|}{$p^{(1)}=0.022^{*}$}} & \multirow{2}{*}{\multicolumn{2}{|c|}{$p^{(1)}=0.067$}} & \multirow{2}{*}{\multicolumn{2}{|c|}{$\mathrm{p}^{(1)}=0.023^{*}$}} \\
\hline Livingwith Parents & & & & & & & & \\
\hline Yes & 69.81 & 15.15 & 71.09 & 13.97 & 69.19 & 22.68 & 55.97 & 16.36 \\
\hline No & 63.49 & 17.93 & 62.50 & 13.34 & 62.96 & 20.88 & 58.33 & 16.54 \\
\hline pValue & $p^{(1)}=$ & 317 & $p^{(1)}=$ & 112 & $p^{(1)}=$ & 405 & $p^{(1)}=$ & 699 \\
\hline
\end{tabular}

(*): Significant difference at 5.0\%.

(1): Mann-Whitney Test.

(2): Kruskal Wallis Test.

the quality of life of adolescents with disabilities. Because of this, the authors had difficulty finding contemporaries who had explored this theme.

According to the Secretary of Education in Pernambuco (SEDUC-PE), hearing impairment is the second-most prevalent disability, behind only mental disability, among students in state schools (12). Visual impairment is less common in schools, a fact confirmed by the Secretary of Education and represented by the group in the present study. Hearing impairments very often have a genetic cause: genetic etiologies are the most prevalent $(67.7 \%)$ amongst individuals seen in preventive programs (16), which is consistent with the results of the present study.

The great majority of adolescents in the current study were in the 15-to-19-year-old age group. This is attributable to the setting of the study, as state schools are responsible for Fundamental II and high school. Another factor is that older students were more likely to be competent to participate in the study despite their disabilities.

We found that the majority of the students with disabilities included in the study (90.5\%) were in classrooms for students who were not necessarily disabled, i.e., regular classrooms. Some studies indicate that inclusion favors the students' exchanging experiences, establishing significant bonds with other students, and becoming active in the acquisition of knowledge (17-19). Inclusion in the regular classroom is important for the quality of life of students with disabilities, a finding confirmed by such individuals' scoring better in the psychological and environmental fields, as well as in social relations, in the present study. The school is an essential environment for the education and the socialization of developing children and adolescents, and school activities can have positive effects on the adolescent's health and well-being $(17,18)$.

The present study found that the lowest QV scores of our subjects were in the environment field. Past studies in 
which the WHOQOL-BREF was administered to adolescents with and without disabilities $(5,19-21)$ also demonstrated that the scores were lower in the environment field than in other fields. This finding is worrisome because some of the factors that contribute to this field cannot be individually controlled but depend on government investments to address pollution, noise, traffic, climate and transport, leisure opportunities, and physical security and safety.

A study in India performed by Agnihotri et al. (22) to test the psychometric validity of the WHOQOL-BREF in 525 adolescents found that the scores were highest in the field of social relationships and lowest in the environment field, consistent with the results of the present study. This corroboration leads us to consider the perception of the environment by adolescents with disabilities to be a worldwide problem.

Nevertheless, a study performed by Teixeira et al. (23) in 74 adolescents and young adults with genetic heart disease in Portugal found the highest QV scores in the environmental and social relations dimensions and the lowest in the physical dimension. This fact suggests that the specific disabilities of the studied subjects influence which field of QV is most affected, as heart disease produces a series of physical limitations. The subjects of the present study do not suffer from physical deficits caused by their individual disabilities. The same was true in the study conducted in Germany by Kamp-Becker et al. (24) to verify the quality of life in 26 adolescents with autism, which also found that the lowest score was in the field of social relations and the highest score in the physical domain.

The psychological field is understood to be important for the studied population, as adolescence is the phase in which the personality is being formed. In this phase of life, the individual is surprised by intense conflicts while searching for an identity (27). Various studies emphasize psychological resources, such as optimism, personal control, and a sense of meaning, as being the reserves that allow people to confront life's critical events in better ways. It is valid to emphasize that psychological well-being can promote healthy behaviors, as people endowed with a sense of selfworth believe in their control over events and are more optimistic about the future, besides being more adept at adopting healthier and more conscious habits (20,28-30).

The global analysis of the quality of life of the subjects under study indicated that some socio-demographic characteristics, such as the classroom socialization of adolescents with disabilities and those without, positively influence the perception of QV. This emphasizes the importance of the field of social relations. An integrative school environment favors the adolescent's self-esteem, helps him or her to manage his or her disability free from prejudice, and makes him or her feel similar to the others, all of which bring benefits.

Age also appears to influence the perception of QV, in that the younger adolescents (10-14 years of age) had better perceptions of their QV. In this phase, the adolescents are still discovering themselves and therefore have not yet completely formed their personalities. As they age, they become more critical and more confrontational and have greater influence on their quality of life (25). In agreement with the findings of the present study, Awasthi et al. (26) found in India that the youngest adolescents reported the highest quality of life scores.

Living with one's parents can also be a positive influence on the quality of life of adolescents, especially those with disabilities. Adolescents who live with their parents are known to feel more sheltered, receive more attention and care, and better succeed in developing themselves socially and cognitively than do those who do not share their lives with parents. This effect was clear in the subjects of the present study, with those who lived with their parents perceiving better QV both in the psychological domain and globally.

\section{CONCLUSION}

In the present study, adolescents with visual deficits perceived better QV than did those who were hearing impaired. Adolescents with impairments perceived the environmental domain as the most worrisome dimension of QV, suggesting a need for greater investments in environmental policies with a view to improving the QV of this population. Students who were included in regular classrooms were verified to report higher scores for quality of life both overall and in the individual domains of psychology, the environment, and social relations. This fact emphasizes the necessity of including adolescents with disabilities in schools, as this will promote the exchange of experiences and bonds of friendship with other students and thus positively influence the perception of quality of life. We emphasize the need to plan additional studies of the quality of life of adolescents with disabilities, as this population is not entitled to express its views on the quality of life and is therefore often neglected.

\section{REFERENCES}

1. Coimbra JAA. Considerações sobre o conceito de qualidade de vida. Petrópolis: Vozes; 1972.

2. Kluthcovsky ACGC, Takayanagui AMM. Qualidade de 
Vida-Aspectos Conceituais. Revista Salus. 2007;1(1):135.

3. Varni JW, Burwinkle TM, Sherman SA, Hanna K, Berrin SJ, Malcarne VL, Chambers HG. Health-related quality of life of children and adolescents with cerebral palsy: hearing the voices of the children. Dev Med Child Neurol. 2005;47(9):592-7.

4. Minayo MCS, Hartz ZMA, Buss, PM. Qualidade de vida e saúde: um debate necessário. CiênSaude Colet. 2000;5(1):718.

5. Gordia AP, Quadros TMB, Vilela Jr GB, Campos W. Variáveissociodemográficas como determinantes do domínio meio a mbiente da qualidade de vida de adolescentes. Ver Ciênc Saúde Colet. 2009;14(16):2261-8.

6. Gordia AP, Quadros TMB, Vilela Jr GB, Oliveira MTC, Campos W. Qualidade devida: contexto histórico, definição, avaliação fatores associados. RevistaBrasileira de Qualidade Vida. 2011;03(1):40-52.

7. Jozefiak T, Larsson B, Wichstrom L, Mattejat F, RavensSieberer U. Quality of Life as reported by school children and their parents: a cross-selectional survey. Healty Qual Life Outcomes. 2008;6:34.

8. Seidl EMF, Zannon C. Qualidade de vida e saúde: aspectos conceituais e metodológicos. Cad Saude Publica. 2004;20(2):580-8.

9. Soares AHR, Martins AJ, Lopes MCB, BrittoJAA, Oliveira CQ, Moreira MCN. Qualidade de vida de crianças e adolescentes: uma revisão bibliográfica. Ciência \& Saúde

Coletiva. 2011;16(7):3197-206.

10. Instituto Brasileiro de Geografia e Estatística IBGE. Censo demográfico de 2010 [Internet]. [cited 2012 Jun 7]. Available from: http://www.censo2010.ibge.gov.br/ resultados_do_censo2010.php

11. Bampi LNS. Percepção de qualidade de vida de pessoas com lesão medular traumática: uma forma de estudar a experiência da deficiência [dissertation]. [Brasília (DF)]: Universidade de Brasília; 2007.

12. Secretaria de Educação de Pernambuco SEDUCPE. Censo escolar de 2010 [Internet]. [cited 2011 Oct 15]. Available from: http://www.educacao.pe.gov.br.

13. Fleck MPA, Louzada S, Xavier M, Chachamovich E, Vieira G, Santos L, Pinzon V. Aplicação da versão em português do instrumento abreviado de avaliação da qualidade de vida "WHOQOL-bref". Rev Saúde Pública. 2000;34(2):17883.

14. Fleck MPA. O instrumento de avaliação de qualidade de vida da Organização Mundial da Saúde (WHOQOL-100): características e perspectivas. Rev Ciênc Saúde Colet. 2000;5(1):33-8.

15. The Whoqol Group. Development of the World Health Organization WHOQOL-bref. Quality of Life Assesment 1998. Psychol Med. 1998;28:551-8.

16. Gatto CI, Tochetto TM. Deficiência auditiva infantil: implicações e soluções. Rev. CEFAC [Internet]. 2007 [cited 2012 Apr 25];9(1):110-5. Available from: http:// www.revistacefac.com.br

17. Novaes RG, Trugillo EA. O aluno surdo no contexto do ensino regular. Rev Eventos Pedagógicos. 2011;2(2):210_ 9.

18 Santos, LHC, Grisotto KP Rodrigues DCB, Bruck I. Inclusão escolar de crianças e adolescentes com paralisia cerebral: esta é uma realidade possível para todas elas em nossos dias?. Rev. paul. pediatr. [online]. 2011;29(3):314-9.

19. Gordia AP, Quadros TMB, Vilela Jr GB, Oliveira MTC, Campos W. Qualidade de vida de adolescentes da rede particular de ensino: comparação entre gêneros. Rev Bras qualidade de vida. 2009;1(2):16-24.

20. Interdonato GC, Greguol, M. Qualidade de vida e prática habitual de atividade física em adolescentes com deficiência. Rev Bras. Crescimento Desenvolv. Hum. [online]. 2011;21(2):282-95.

21. Izutsu T, Tsutsumi A, Islam A, Matsuo Y, Yamada HS, Kurita H, WakaiS. Validity and reliability of the Bangla version of WHOQOLBREF on an adolescent population in

Bangladesh. Qual Life Res. 2005;14(7):1783-9.

22. Agnihotri K, Awasthi S, Chandra H, Singh U, Thakur S. Validation of WHO QOL-BREF instrument in Indian adolescents. Indian Journal of Pediatrics. 2010;77(4):3816.

23. Teixeira FM, Coelho RM, Proença C, Silva AM, Vieira D, VazC. Quality of life experienced by adolescents and young adults with congenital heart disease. Pediatric cardiology [Internet]. 2011 Dec [cited 2012 May 27];32(8):1132-8. Available from: http://www.ncbi.nlm.nih.gov/pubmed/ $\underline{21710181 .}$.

24. Kamp-Becker I, Schröder J, Remschmidt H, Bachmann 
CJ. Health-related quality of life in adolescents and young adults with high functioning autism-spectrum disorder. GMS Psycho Social Medicine. 2010;7:1-10.

25. Ravens-Sieberer U, Torsheim T, Hetland J, Vollebergh W, Cavallo F, Jericek H, et al. Subjective health, symptom load and quality of life of children and adolescents in Europe. International Journal of Public Health. 2009;54:151-9.

26. Awasthi S, Agnihotri K, Singh U, Thakur S, Chandra H. Determinants of health related quality of life in school-going adolescents in Northern India. Indian Journal of Pediatrics [Internet]. 2011;78(5):555-61. Available from: http:// www.ncbi.nlm.nih.gov/pubmed/21267797.

27. Davim RMB, Germano RM, Menezes RMV, Carlos DJD. Adolescente/adolescência: revisão teórica sobre uma fase crítica da vida. Rev Rene. 2009;10(2):131-40.

28. Pereira RJ, Cotta RMM, Franceschini SCC, Ribeiro RCL, Sampaio RF, Priore SE Cecon PR. Contribuição dos domínios físico, social, psicológico e ambiental para a qualidade de vida global de idosos. Rev. Psiquiatr. 2006;28(1):27-38.
29. Rabelo DF, Néri AL. Recursos psicológicos e ajustamento pessoal frente à incapacidade funcional na velhice. Psicol Estud. 2005;10:403.

30. Gordia AP, DeQuadros TMB, De Campos W, Petroski EL. Adolescents' physical quality of life: associations with physical activity and sex. Revista De Salud Publica Bogota Colombia [Internet]. 2009;11(1):50-61. Available from: http:// search.ebscohost.com/login.aspx?direct=true H Y PERLINK"http:// search.ebscohost.com/ login.aspx?direct $=$ true $\& \mathrm{db}=\mathrm{cmedm} \& A N=19721979 \&$ site $=$ ehost-live"\&HYPERLINK"http://search.ebscohost.com/ login.as px?direct $=\mathrm{true} \& \mathrm{db}=\mathrm{c}$ med $\mathrm{m} \& \mathrm{AN}=$ 19721979\&site=ehostlive" db=cmedmHYPERLINK "http:// search.ebscohost.com/login.aspx?direct=true \&db= cmedm\&AN=19721979\&site=ehostlive"\&HYPERLINK "http://search.ebscohost.com/login.aspx? direct $=$ true $\& d b=c$ medm\&AN $=19721979 \&$ site $=$ ehostlive"AN=19721979HYPERLINK "http://search. b s cohost. $\operatorname{com} / \log$ in.aspx?direct $=$ true $\&$ db $=$ cmedm\&AN=19721979\&site=ehost-live"\&HYPERLINK "http://search.ebscohost.com login.aspx?direct=true\& $\mathrm{db}=\mathrm{cmedm \& AN}=19721979 \&$ site $=$ ehost-live"site $=$ ehost-live . 